\title{
MIR181A1 wt Allele
}

National Cancer Institute

\section{Source}

National Cancer Institute. MIR181A1 wt Allele. NCI Thesaurus. Code C82112.

Human MIR181A1 wild-type allele is located in the vicinity of 1q31.3 and is 109 bases in length. This allele, which encodes MIR181A1 pre-miRNA, plays a role in the regulation of gene expression. Alteration in the expression of this gene is associated with the development of glioma and multiple myeloma. 